\title{
Thiazolidinediones Modulate the Expression of $\beta$-Catenin and Other Cell-Cycle Regulatory Proteins by Targeting the F-Box Proteins of Skp1-Cul1-F-box Protein E3 Ubiquitin Ligase Independently of Peroxisome Proliferator-Activated Receptor $\gamma$
}

\author{
Shuo Wei, Li-Fang Lin, Chih-Cheng Yang, Yu-Chieh Wang, Geen-Dong Chang, \\ Hungwen Chen, and Ching-Shih Chen \\ Division of Medicinal Chemistry, College of Pharmacy, the Ohio State University, Columbus, Ohio (S.W., L.-F.L., C.-C.Y., \\ Y.-C.W., C.-S.C.); Graduate Institute of Biochemical Sciences, National Taiwan University, Taipei, Taiwan (G.-D.C.); Institute of \\ Biological Chemistry, Academia Sinica, Nankang, Taipei, Taiwan (H.C.)
}

Received February 17, 2007; accepted June 14, 2007

\begin{abstract}
Considering the role of aberrant $\beta$-catenin signaling in tumorigenesis, we investigated the mechanism by which the peroxisome proliferator-activated receptor $\gamma$ (PPAR $\gamma$ ) agonist troglitazone facilitated $\beta$-catenin down-regulation. We demonstrate that troglitazone and its more potent PPAR $\gamma$-inactive analogs $\Delta 2 \mathrm{TG}$ and STG28 mediated the proteasomal degradation of $\beta$-catenin in prostate cancer cells by up-regulating the expression of $\beta$-transducin repeat-containing protein ( $\beta$-TrCP), an F-box component of the Skp1-Cul1-F-box protein E3 ubiquitin ligase. Evidence indicates that although small interfering RNA-mediated $\beta$-TrCP knockdown protected cells against STG28-facilitated $\beta$-catenin ablation, ectopic $\beta$-TrCP expression enhanced the degradation. The involvement of $\beta$-TrCP in $\beta$-catenin degradation was also corroborated by the pull-down analysis and the concurrent down-regulation of known $\beta$-TrCP substrates examined, including Wee1, $\mid \kappa \beta \alpha$, cdc25A, and nuclear factor $-\kappa \mathrm{B} / \mathrm{p} 105$. Furthermore,
\end{abstract}

glycogen synthase kinase- $3 \beta$ represented a key regulator in the effect of these thiazolidinedione derivatives on $\beta$-catenin proteolysis even though these agents increased its phosphorylation level. It is noteworthy that this drug-induced $\beta$-TrCP up-regulation was accompanied by the concomitant down-regulation of Skp2 and Fbw7, thereby affecting many of the target proteins of these two F-box proteins (such as p27 and cyclin E). As a consequence, the ability of troglitazone to target these F-box proteins provides a molecular basis to account for its reported effect on modulating the expression of aforementioned cell-cycle regulatory proteins. Despite this complicated mode of pharmacological actions, normal prostate epithelial cells, relative to LNCaP cells, were less susceptible to the effects of STG28 on modulating the expression of $\beta$-catenin and $\beta$-TrCP, suggesting the translation potential of using STG28 as a scaffold to develop more potent chemopreventive agents.
Substituted thiazolidinediones such as troglitazone, ciglitazone, and rosiglitazone belong to a family of oral antidiabetic drugs that increase insulin sensitivity in adipose tissue, muscle, and liver primarily through the activation of perox-

This work was supported by National Institutes of Health grant CA112250, Department of Defense Prostate Cancer Research Program Award W81XWH05-1-0089, and a Prostate Cancer Foundation Competitive Award.

Article, publication date, and citation information can be found at http://molpharm.aspetjournals.org.

doi:10.1124/mol.107.035287. isome proliferator-activated receptor $\gamma(\operatorname{PPAR} \gamma)$ (Day, 1999). It is well-documented that ligand activation of PPAR $\gamma$ can regulate multiple crucial biological processes including growth, differentiation, and apoptosis through the transcriptional expression of insulin-sensitive genes involved in glucose metabolism and energy balance. It is noteworthy that these agents at high doses exhibit in vitro and in vivo antitumor effects against many types of cancers, including colon, breast, and prostate (Koeffler, 2003; Weng et al., 2006). However, recent evidence indicates that the effect of thiazo-

ABBREVIATIONS: PPAR $\gamma$, peroxisome proliferator-activated receptor $\gamma$; SCF, Skp1-Cul1-F-box protein; $\beta$-TrCP, $\beta$-transducin repeat-containing protein; GSK3 $\beta$, glycogen synthase kinase $3 \beta$; PrECs, normal prostate epithelial cells; MTT, 3-(4,5-dimethylthiazol-2-yl)-2,5-diphenyl-2Htetrazolium bromide; GST, glutathione transferase; APC, adenomatous polyposis coli; siRNA, small interfering RNA; DMSO, dimethyl sulfoxide; $\mathrm{HA}$, hemagglutinin; NF $\kappa$ B, nuclear factor $\kappa \mathrm{B}$; FBS, fetal bovine serum; PCR, polymerase chain reaction; TBST, Tris-buffered saline/Tween 20; PI, propidium iodide; PBS, phosphate-buffered saline; TG, troglitazone; MG132, N-benzoyloxycarbonyl (Z)-Leu-Leu-leucinal; SB216763, 3-(2,4dichlorophenyl)-4-(1-methyl-1H-indol-3-yl)-1H-pyrrole-2,5-dione; ZVAD-fmk, benzyloxycarbonyl-Val-Ala-Asp fluoro-methylketone; E-64, $\mathrm{N}$-(transepoxysuccinyl)-L-leucine 4-guanidinobutylamide; GW9662, 2-chloro-5-nitro- $N$-phenyl-benzamide. 
lidinediones on differentiation, cell cycle, and apoptosis in these cancer cells might involve both PPAR $\gamma$-dependent and -independent pathways (Sugimura et al., 1999; Motomura et al., 2000; Okura et al., 2000; Gouni-Berthold et al., 2001; Takeda et al., 2001; Bae and Song, 2003; Baek et al., 2003; Huang et al., 2005; Shiau et al., 2005; Yang et al., 2006). In light of the chemopreventive potential of PPAR $\gamma$ agonists, it is crucial to delineate the mechanism by which these agents mediate antitumor effects.

Among various signaling mechanisms targeted by the thiazolidinedione family of PPAR $\gamma$ agonists, the ability of troglitazone to facilitate the proteasomal degradation of a series of cell-cycle regulatory proteins such as cyclin D1 (Qin et al., 2003; Huang et al., 2005) and $\beta$-catenin (Moldes et al., 2003; Liu and Farmer, 2004; Sharma et al., 2004) is especially noteworthy. For example, PPAR $\gamma$-facilitated adipocyte differentiation is associated with an extensive down-regulation of $\beta$-catenin expression (Moldes et al., 2003), suggesting a crosstalk between these two signaling pathways. $\beta$-Catenin is a dual-function protein that regulates cell adhesion and transcription in different subcellular compartments (Bienz, 2005; Harris and Peifer, 2005; Brembeck et al., 2006). In the cytoplasm and nucleus, $\beta$-catenin regulates the transcription of target genes crucial to cell proliferation and differentiation through the Wnt signaling cascade, whereas at the plasma membrane, it controls E-cadherin-mediated cell adhesion. Through the integration of these two signaling networks, $\beta$-catenin plays a pivotal role in maintaining the integrity of cellular functions. Substantial evidence indicates that dysregulation of $\beta$-catenin signaling contributes to human malignancies as a result of a loss of cell-cell adhesion and increased transcription of Wht target genes (Wong and Pignatelli, 2002; Verras and Sun, 2006). As a result, targeting $\beta$-catenin expression represents a viable strategy for therapeutic and/or preventive intervention.

In this study, we used PPAR $\gamma$-inactive analogs of troglitazone, $\triangle 2$ TG and STG28, to discern the involvement of PPAR $\gamma$ in troglitazone-mediated suppression of $\beta$-catenin expression in prostate cancer cells. Several lines of evidence indicate that the effect of these thiazolidinediones on glycogen synthase kinase-3 $\beta$ (GSK3 $\beta$ )-dependent repression of $\beta$-catenin was attributable to ubiquitination-dependent proteasomal degradation independently of PPAR $\gamma$. Moreover, the enhanced ubiquitination of $\beta$-catenin was associated with increased accumulation of the F-box protein $\beta$-TrCP ( $\beta$-transducin repeat-containing protein) (Kitagawa et al., 1999; Latres et al., 1999; Liu et al., 1999; Winston et al., 1999) of the Skp1-Cul1-F-box protein (SCF) complex through protein stabilization. From a translational perspective, the high potency of STG28 in facilitating $\beta$-catenin degradation provides a proof-of-principle that potent $\beta$-catenin-ablating agents could be developed through structural optimization of troglitazone.

\section{Materials and Methods}

Reagents. Troglitazone, MG132, epoxomicin, lithium chloride, and SB216763 were purchased from Sigma-Aldrich (St. Louis, MO). ZVAD-fmk was obtained from Calbiochem (San Diego, CA). The PPAR $\gamma$-inactive thiazolidinedione derivatives $\Delta 2$ TG and STG28 (Huang et al., 2005; Yang et al., 2006) were synthesized according to a published procedure (Huang et al., 2006). These agents were added to medium with a final DMSO concentration of $0.1 \%$. Antibodies against various proteins were obtained from the following sources: mouse monoclonal antibodies: PPAR $\gamma, \beta$-catenin, Wee1, nucleolin, and $\mathrm{Na}^{+} / \mathrm{K}^{+}$ATPase $\alpha$ were from Santa Cruz Biotechnology (Santa Cruz, CA); HA and Myc were from Roche (Indianapolis, IN); $\beta$-TrCP, Skp2, and Fbw7 were from Invitrogen (Carlsbad, CA); $\beta$-actin was from MP Biomedicals (Irvine, CA); rabbit antibodies p-Ser33/Ser37/ Thr41 $\beta$-catenin, p-Ser9-GSK3 $\beta$, GSK3 $\beta$, Cdc25A, NF $\kappa$ B/p105, poly(ADP-ribose) polymerase, and caspase 3 were from Cell Signaling Technology (Danvers, MA); and $\mathrm{I} \kappa \mathrm{B} \alpha, \mathrm{p} 21, \mathrm{p} 27$, and cyclin E were from Santa Cruz Biotechnology.

Cell Culture. LNCaP, DU145, and PC-3 prostate cancer cells were purchased from the American Type Culture Collection (Manassas, VA). Cells were cultured in T-75 flasks with RPMI 1640 medium containing $10 \%$ heat-inactivated fetal bovine serum (FBS) at $37^{\circ} \mathrm{C}$ in a humidified incubator containing $5 \% \mathrm{CO}_{2}$. Normal prostate epithelial cells (PrECs) were obtained from Lonza Walkersville (Walkersville, MD) and maintained in defined prostate epithelial growth medium recommended by the vendor.

RNA Isolation and Reverse Transcription-PCR Analysis. After vehicle or drug treatments, $\mathrm{LNCaP}$ cells were subject to total RNA isolation by using an RNeasy mini kit (QIAGEN, Valencia, CA). RNA concentrations were determined by measuring absorption at $260 \mathrm{~nm}$ in a spectrophotometer. Aliquots of $6 \mu \mathrm{g}$ of total RNA from each sample were reverse-transcribed to cDNA using an Omniscript RT Kit (QIAGEN) according to the manufacturer's instructions. PCR primers used in this study included the following: $\beta$-catenin, 5 ' CTGATTTGATGGAGTTGGAC-3' and 5'-TATCAGCTACTTGTTCTTGAG-3'; $\beta$ TrCP, 5'-CACTTAGACACATACAACA-3' and 5'-TCTGCAACATAGGTTTAAGAT- $3^{\prime}$; and $\beta$-actin, $5^{\prime}$-TCTACAATGAGCT GCGTGTG-3' and 5'-GGTCAGGATCTTCATGAGGT-3'. PCR reaction products were separated electrophoretically in $1.5 \%$ agarose gels and visualized by ethidium bromide staining.

Cell Viability Assay. Cell viability was assessed by using the 3-(4,5-dimethylthiazol-2-yl)-2,5-diphenyl-2H-tetrazolium bromide (MTT) assay in six replicates (96-well format). PrECs and LNCaP cells were seeded at 8000 and 3000 cells per well, respectively, in 96 -well flat-bottomed plates, and incubated for $24 \mathrm{~h}$ in $10 \%$ FBSprostate epithelial growth medium and 10\% FBS-supplemented RPMI 1640 medium, respectively. Cells were then treated with DMSO, troglitazone, or STG28 at various concentrations in the presence of $10 \mu \mathrm{M}$ MG132 or $100 \mu \mathrm{M}$ ZVAD-fmk. Controls received DMSO at a concentration equal to that in drug-treated cells. After $48 \mathrm{~h}, 1 / 10$ volume of $10 \times \mathrm{MTT}$ ( $5 \mathrm{mg} / \mathrm{ml}$ ) was added to each well, and cells were incubated at $37^{\circ} \mathrm{C}$ for $2 \mathrm{~h}$. Medium was removed and the reduced MTT dye was solubilized in $200 \mu \mathrm{l} /$ well DMSO. Absorbance was determined at $570 \mathrm{~nm}$.

Immunoblotting. Cells in T-75 flasks were harvested by scraping, and cell lysates were prepared using a commercial lysis buffer (Mammalian Protein Extraction Reagent; Pierce, Rockford, IL) in the presence of a $1 \%$ protease inhibitor cocktail (Calbiochem). After centrifugation for $20 \mathrm{~min}, 2 \mu \mathrm{l}$ of the suspension was taken for protein determination using a Bradford assay kit (Bio-Rad, Hercules, CA). To the remaining solution was added the same volume of $2 \times$ SDS polyacrylamide gel electrophoresis sample loading buffer (100 mM Tris-HCl, pH 6.8, 4\% SDS, 5\% $\beta$-mercaptoethanol, 20\% glycerol, and $0.1 \%$ bromphenol blue) and boiled for $10 \mathrm{~min}$. Equal amounts of protein were resolved in 10\% SDS-polyacrylamide gels. After electrophoresis, gel was transferred to nitrocellulose membranes using a semidry transfer cell. The transblotted membrane was washed twice with Tris-buffered saline containing $0.1 \%$ Tween 20 (TBST). After blocking with TBST containing $5 \%$ nonfat milk for $1 \mathrm{~h}$, the membrane was incubated with the appropriate primary antibody (diluted 1:1000) in $1 \%$ TBST nonfat milk at $4^{\circ} \mathrm{C}$ overnight. After incubation with the primary antibody, the membrane was washed three times with TBST for a total of 30 min followed by incubation with horseradish peroxidase-conjugated goat anti-rabbit or anti-mouse IgG (diluted 1:2500) for $1 \mathrm{~h}$ at room temperature. After 
three times of extensive wash with TBST for a total of $30 \mathrm{~min}$, the immunoblots were visualized by enhanced chemiluminescence.

Flow Cytometry Analysis of Apoptosis. Cells were seeded in six-well plates at a density of $5 \times 10^{5}$ cells/well, and after overnight incubation, they were exposed to $10 \mu \mathrm{M}$ STG28 for different time intervals. Both floating and adherent cells were collected, and stained with annexin V-Alexa Fluor 488 and propidium iodide (PI) according to the vendor's protocols (Invitrogen). The analysis of annexin V/PI staining was performed using a FACSCalibur fluorescence-activated cell sorter (Becton Dickinson Immunocytometry Systems, San Jose, CA) equipped with CellQuest software.

Cell Fractionation. LNCaP cells were incubated with $10 \% \mathrm{FBS}-$ supplemented RPMI 1640 medium for $24 \mathrm{~h}$ and exposed to $10 \mu \mathrm{M}$ STG28 treatment for different time intervals. Collected cells were lysed and fractionated by using a Qproteome Cell Compartment kit (QIAGEN) according to the manufacturer's instructions. In brief, treated cells were washed twice with PBS and incubated with extraction buffer $\mathrm{CE} 1$ for $10 \mathrm{~min}$ at $4^{\circ} \mathrm{C}$. After 10-min centrifugation at $1000 \mathrm{~g}$ at $4^{\circ} \mathrm{C}$, supernatants were collected as cytosolic fraction, and pellets were subject to extraction buffer CE2 at $4^{\circ} \mathrm{C}$ for $30 \mathrm{~min}$. The lysates were centrifuged at $6000 \mathrm{~g}$ for $10 \mathrm{~min}$ at $4^{\circ} \mathrm{C}$ to obtain supernatants as membrane fraction. Pellets were further incubated with nuclease at room temperature for $15 \mathrm{~min}$ followed by extraction buffer CE3 for $10 \mathrm{~min}$ at $4^{\circ} \mathrm{C}$. After nuclear membrane was solubilized, nuclear fractions were obtained from the supernatant by centrifugation at $6800 \mathrm{~g}$ for $10 \mathrm{~min}$ at $4^{\circ} \mathrm{C}$. Subcellular fractions were quantitated and subjected to immunoblotting for $\beta$-catenin detection. $\mathrm{Na}^{+} / \mathrm{K}^{+}$ATPase $\alpha$, nucleolin, and $\beta$-actin served as markers and internal controls for membrane, nuclear, or cytosolic compartments, respectively.

Transient Transfection and RNA Interference. Transfection of LNCaP cells was performed by electroporation using an Amaxa Nucleofector with a cell line-specific nucleofector kit according to the manufacturer's protocol (Amaxa Biosystems, Cologne, Germany) with the HA-tag ubiquitin plasmid or the pMyc4-h $\beta$ TrCP-CMV14 plasmid encoding Myc-tagged full-length $\beta \operatorname{TrCP}$ (Yang et al., 2005). The nucleofected cells were seeded in six-well plates at $5 \times 10^{5}$ cells/well and incubated in 10\% FBS-containing medium for $24 \mathrm{~h}$ before drug treatment. The transfection efficiency was determined to be 70 to $80 \%$ by electroporating cells with $2 \mu \mathrm{g}$ of pmaxGFP plasmids (Amaxa) followed by fluorescence microscopy to measure green fluorescent protein expression. For siRNA experiments, PC3 and LN$\mathrm{CaP}$ cells were electroporated with siRNA against PPAR $\gamma$ (Upstate Biotechnology, Lake Placid, NY) and or $\beta \operatorname{TrCP}$ siRNA (Santa Cruz), respectively, with the respective scrambled siRNA as control. Cells were seeded in six-well plates $\left(5 \times 10^{5}\right.$ cells/well $)$ and incubated for $24 \mathrm{~h}$. After $10 \mu \mathrm{M}$ STG28 treatment for an additional 24 or $48 \mathrm{~h}$, cells were lysed, and protein extracts were prepared for Western blot analysis.

Immunoprecipitation. $\mathrm{LNCaP}$ cells were nucleofected with $5 \mu \mathrm{g}$ of HA-ubiquitin plasmids, incubated in six-well plates for $24 \mathrm{~h}$, and treated with $60 \mu \mathrm{M}$ troglitazone, $40 \mu \mathrm{M} \Delta 2 \mathrm{TG}$, or $10 \mu \mathrm{M}$ STG28 for 20 or $44 \mathrm{~h}$ followed by cotreatment with the proteasome inhibitor MG132 for an additional $4 \mathrm{~h}$. After harvest, cells were lysed by radioimmunoprecipitation assay lysis buffer (Santa Cruz) with freshly added phosphatase and protease inhibitors consisting of 100 $\mu \mathrm{M}$ 4-(2-aminoethyl)-benzenesulfonyl fluoride, $80 \mathrm{nM}$ aprotinin, 5 $\mu \mathrm{M}$ bestatin, $1.5 \mu \mathrm{M}$ E-64 protease inhibitor, $2 \mu \mathrm{M}$ leupeptin, $1 \mu \mathrm{M}$ pepstatin A, $2 \mathrm{mM}$ imidazole, $1 \mathrm{mM}$ sodium fluoride, $1 \mathrm{mM}$ sodium molybdate, $1 \mathrm{mM}$ sodium orthovanadate, and $4 \mathrm{mM}$ sodium tartrate dihydrate. After centrifugation at $13,000 \mathrm{~g}$ for $20 \mathrm{~min}$, the supernatant was collected, preincubated with protein A-Agarose (Santa Cruz) for $15 \mathrm{~min}$, and centrifuged at $1000 \mathrm{~g}$ for $5 \mathrm{~min}$. One tenth of the supernatant was stored at $4^{\circ} \mathrm{C}$ to be used as input, and the remainder was exposed to anti- $\beta$-catenin antibody and protein-A agarose at $4^{\circ} \mathrm{C}$ for $12 \mathrm{~h}$. After brief centrifugation, immunoprecipitates were collected, washed with the aforementioned lysis buffer twice, sus- pended in $2 \times$ SDS sample buffer, and subjected to Western blot analysis with antibodies against $\mathrm{HA}$ and $\beta$-catenin.

Preparation of Glutathione Transferase- $\beta$-TrCP Fusion Protein. The $\mathrm{pMyc} 4$-h $\beta$ TrCP-CMV14 plasmid encoding Myc-tagged full-length $\beta \mathrm{TrCP}$ was subcloned into BamHI/EcoRI sites of pGEX vector for glutathione transferase (GST)- $\beta$-TrCP fusion protein expression. The resulting pGEX- $\beta$-TrCP plasmid was verified by DNA sequencing. The GST- $\beta$-TrCP recombinant protein was expressed in Escherichia coli by isopropyl-1-thio- $\beta$-D-galactopyranoside induction. After overnight incubation, bacteria were lysed in PBS containing 1 $\mathrm{mg} / \mathrm{ml}$ lysozyme (Pierce) and sonicated for $5 \mathrm{~min}$. The bacterial lysates were subjected to Western blot analysis for fusion protein identification. Recombinant GST- $\beta$-TrCP fusion protein was purified by using glutathione-Sepharose beads (GE Healthcare, Chalfont St. Giles, Buckinghamshire, UK) with gentle rocking at $4^{\circ} \mathrm{C}$ for $2 \mathrm{~h}$ according to the manufacturer's protocol. Equal amounts of GST protein were prepared as control in a similar manner. The fusion protein immobilized onto glutathione beads was washed three times with ice-cold PBS buffer and used directly for the following GST pull-down assay.

GST Pull-Down Assay. LNCaP cells were seeded and incubated in 10\% FBS-containing RPMI 1640 medium in T-25 flasks for $48 \mathrm{~h}$ and then exposed to $10 \mu \mathrm{M}$ STG28 for $24 \mathrm{~h}$ with or without $10 \mu \mathrm{M}$ epoxomicin. Cells were lysed by PBS buffer containing $1 \%$ Triton X-100 and a protease inhibitor cocktail (Calbiochem), incubated with glutathione beads for $2 \mathrm{~h}$, and then incubated with equal amounts of GST- or GST- $\beta$-TrCP-immobilized glutathione beads at $4^{\circ} \mathrm{C}$ for $4 \mathrm{~h}$. The incubation mixtures were washed three times with PBS containing $1 \%$ Triton $\mathrm{X}-100$, and the resulting precipitates were subjected to Western blot analysis with mouse antibodies against $\beta$-catenin and $\beta \mathrm{TrCP}$ and goat antibody against GST.

\section{Results}

Troglitazone-Mediated Repression of $\beta$-Catenin Is Attributable to an "Off-Target" Mechanism. We obtained four lines of evidence that the effect of troglitazone on suppressing $\beta$-catenin expression was dissociated from PPAR $\gamma$ activation. First, we investigated the effect of troglitazone on $\beta$-catenin repression in three prostate cancer cell lines with differential PPAR $\gamma$ expression: DU-145, LNCaP, and PC-3 in 10\% FBS-supplemented medium. Although LN$\mathrm{CaP}$ cells expressed substantially lower levels of PPAR $\gamma$ relative to DU-145 and PC-3 cells, these three cell lines were equally susceptible to troglitazone-mediated $\beta$-catenin downregulation (Fig. 1A). Second, we examined the dose-dependent effect of a potent PPAR $\gamma$ antagonist, GW9662 (Leesnitzer et al., 2002; Seargent et al., 2004), on troglitazone-facilitated $\beta$-catenin repression in PC-3 cells. Even at concentrations 3 orders of magnitude higher than the $\mathrm{IC}_{50}$ value in PPAR $\gamma$ binding, GW9662 had no appreciable effect on $\beta$-catenin expression and did not prevent troglitazonemediated $\beta$-catenin repression (Fig. 1B). Third, we assessed the effect of two PPAR $\gamma$-inactive analogs of troglitazone, $\Delta 2 T G$ and STG28 (Huang et al., 2005, 2006; Yang et al., 2006), compared with troglitazone on intracellular $\beta$-catenin in LNCaP cells. As evidenced by PPRE-luciferase reporter assay, $\triangle 2$ TG and STG28 lacked appreciable activity in PPAR $\gamma$ transactivation (Fig. 1C, top). Both agents, however, were effective in suppressing $\beta$-catenin expression. In particular, the PPAR $\gamma$-inactive analog STG28 exhibited multifold higher potency than troglitazone (bottom), providing a proofof-principle that the ability of troglitazone to repress $\beta$-catenin could be pharmacologically exploited to develop a novel class of $\beta$-catenin-ablative agents. Fourth, siRNA-mediated 
knockdown of PPAR $\gamma$ in PC-3 cells exhibited no appreciable effect on STG28-induced suppression of $\beta$-catenin (Fig. 1D).

STG28 Stimulates Tumor Cell-Specific Repression of $\boldsymbol{\beta}$-Catenin via Proteasomal Degradation. Figure 2A depicts the time-dependent effect of troglitazone $(60 \mu \mathrm{M}), \Delta 2 \mathrm{TG}$ $(40 \mu \mathrm{M})$, and STG28 $(10 \mu \mathrm{M})$ on $\beta$-catenin expression in LNCaP cells at both protein and mRNA levels. Although treatment with these agents led to a progressive decrease in $\beta$-catenin protein levels, the mRNA level remained largely unaltered throughout the course of study, suggesting that the drug-induced $\beta$-catenin repression was mediated at the post-transcriptional stage. We further investigated the temporal and spatial effects of $10 \mu \mathrm{M}$ STG28 on $\beta$-catenin in different cellular compartments of LNCaP cells via cellular fractionation (Fig. 2B). Western blot analysis indicates that

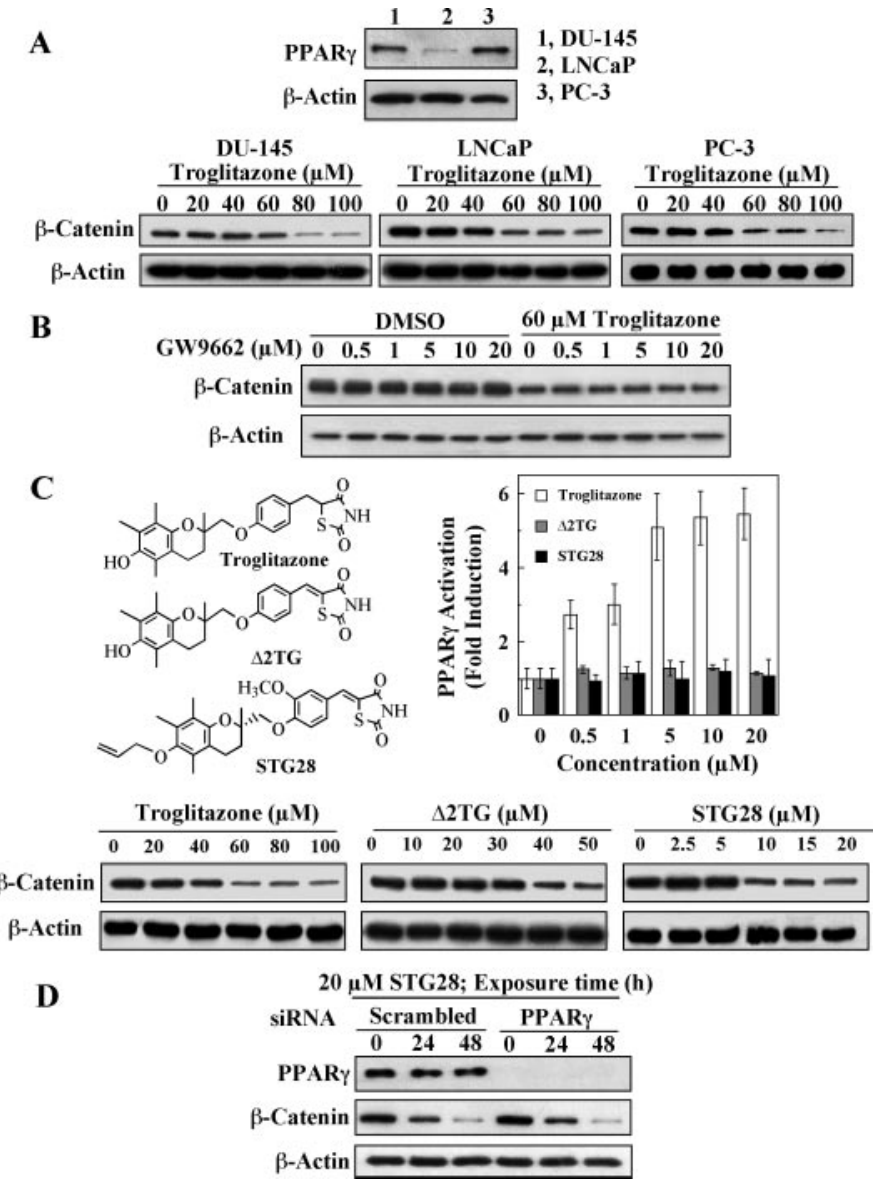

Fig. 1. Pharmacological evidence that thiazolidinedione-mediated downregulation of $\beta$-catenin is independent of PPAR $\gamma$ activation. A, troglitazone mediates $\beta$-catenin repression in DU-145, LNCaP, and PC-3 cells with similar potency irrespective of their PPAR $\gamma$ expression levels. Top, expression levels of PPAR $\gamma$ in DU-145, LNCaP, and PC-3 cells. Bottom, dose-dependent effect of troglitazone on suppressing $\beta$-catenin expression in these three cell lines. Cells were exposed to different doses of troglitazone in 10\% FBS-supplemented RPMI 1640 medium for $72 \mathrm{~h}$. B, the PPAR $\gamma$ antagonist GW9662, at a dose range of 0 to $20 \mu \mathrm{M}$, could not rescue troglitazone-mediated $\beta$-catenin repression in PC-3 cells. C, the PPAR $\gamma$-inactive analogs $\Delta 2$ TG and STG28 are effective in repressing $\beta$-catenin. Top, chemical structures of troglitazone, $\Delta 2 \mathrm{TG}$, and STG28 and evidence that $\Delta 2 \mathrm{TG}$ and STG28 are devoid of activity in PPAR $\gamma$ activation using a luciferase reporter assay in PC-3 cells as described under Materials and Methods. Columns, means; bars, S.D. $(n=6)$. Bottom, dose-dependent effect of troglitazone, $\Delta 2 \mathrm{TG}$, and STG28 on repressing $\beta$-catenin in LNCaP cells $10 \%$ FBS-supplemented medium after 72-h exposure. D, siRNA-mediated knockdown of PPAR $\gamma$ does not interfere with the effect of STG28 on $\beta$-catenin repression. $\beta$-catenin was mainly localized to the membrane and cytoplasm and that in response to STG28, cytoplasmic $\beta$-catenin disappeared at much faster rates than the membrane-bound counterpart. After 48 h of drug treatment, whereas cytoplasmic $\beta$-catenin was eliminated to a great extent, significant amounts of $\beta$-catenin still remained on cytoplasmic membranes.

Relative to LNCaP cells, PrECs were resistant to STG28's effect on suppressing $\beta$-catenin expression and cell viability (Fig. 2C). As shown, exposure of PrECs to $10 \mu \mathrm{M}$ STG28 did not cause a significant reduction in $\beta$-catenin expression (left). This discriminatory effect underscored the differential susceptibility of LNCaP cells versus PrECs to the inhibitory effect of STG28 on cell viability via MTT assay (right; 48-h treatment).

From a mechanistic perspective, the effect of STG28 on suppressing $\beta$-catenin expression might be facilitated by two distinct mechanisms: proteasomal degradation, and apoptosis-induced cleavage by caspase-3 (Steinhusen et al., 2000). We obtained two lines of evidence to refute the possible involvement of caspase-3 in the drug action. First, STG28-

$\mathbf{A}$
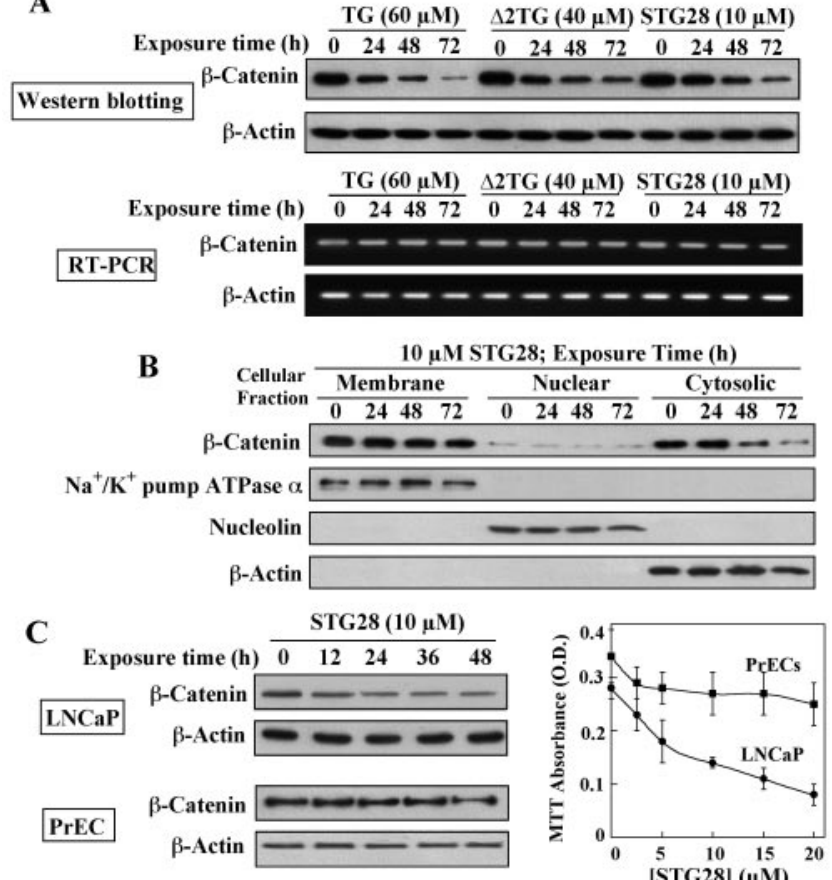

D

STG28 $(10 \mu \mathrm{M})$; Exposure time [STG28] $(\mu \mathrm{M})$

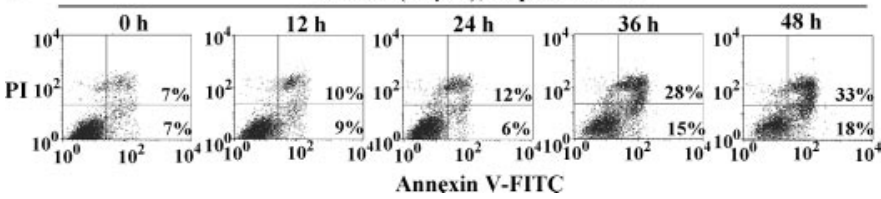

Fig. 2. Troglitazone, $\Delta 2 \mathrm{TG}$, and STG28 repress $\beta$-catenin at the posttranscriptional level in LNCaP cells, and the differential inhibitory effect of STG28 on $\beta$-catenin expression and cell viability in LNCaP versus PrECs. A, time-dependent effect of troglitazone (TG), $\Delta 2 \mathrm{TG}$, and STG28 on suppressing $\beta$-catenin protein (top) and mRNA (bottom) levels in LNCaP cells in $10 \%$ FBS-supplemented medium. B, time-dependent effect of $10 \mu \mathrm{M}$ STG28 on suppressing $\beta$-catenin expression in different cellular compartments of LNCaP cells. C, differential effects of STG28 on suppressing $\beta$-catenin protein expression (left) and cell viability (right) in LNCaP cells versus PrECs. Cell viability was determined at $48 \mathrm{~h}$ of drug treatment. D, flow cytometric analysis of the time-dependent effect of 10 $\mu \mathrm{M}$ STG28 on inducing apoptosis in LNCaP cells via annexin V staining. 
mediated $\beta$-catenin repression preceded apoptosis. As evidenced by Annexin V/PI staining (Fig. 2D), STG28-induced apoptosis in LNCaP cells occurred predominantly $36 \mathrm{~h}$ after drug treatment compared with $24 \mathrm{~h}$ for $\beta$-catenin repression (C). Second, the proteasome inhibitor MG132, but not the caspase inhibitor ZVAD-fmk, could protect LNCaP cells from troglitazone and STG28-mediated suppression of $\beta$-catenin expression (Fig. 3A, left). As shown, whereas MG132 exhibited a complete protection, blockade of caspase-3 activation by the pan caspase inhibitor had no apparent effect on counteracting troglitazone- or STG28-facilitated ablation. In contrast, PrECs were not susceptible to the repressing effect of either agent irrespective of the presence of MG132 or ZVADfmk (right).

Because proteasome-facilitated proteolysis is preceded by ubiquitination, we examined the formation of ubiquitinated $\beta$-catenin in ectopic HA-ubiquitin-expressing LNCaP cells in response to troglitazone $(60 \mu \mathrm{M}), \Delta 2 \mathrm{TG}(40 \mu \mathrm{M})$, and STG28 (10 $\mu \mathrm{M})$ (Fig. 3B). Cell were exposed to individual agents for 20 or $44 \mathrm{~h}$, cotreated with $10 \mu \mathrm{M}$ MG132 for an additional $4 \mathrm{~h}$, and cell lysates were immunoblotted with $\beta$-catenin antibodies (input) or immunoprecipitated by anti- $\beta$-catenin antibody-agarose conjugates. Equivalents amounts of the immunoprecipitated proteins were subject to Western blotting with HA or $\beta$-catenin antibodies. As shown, treatment with indi-
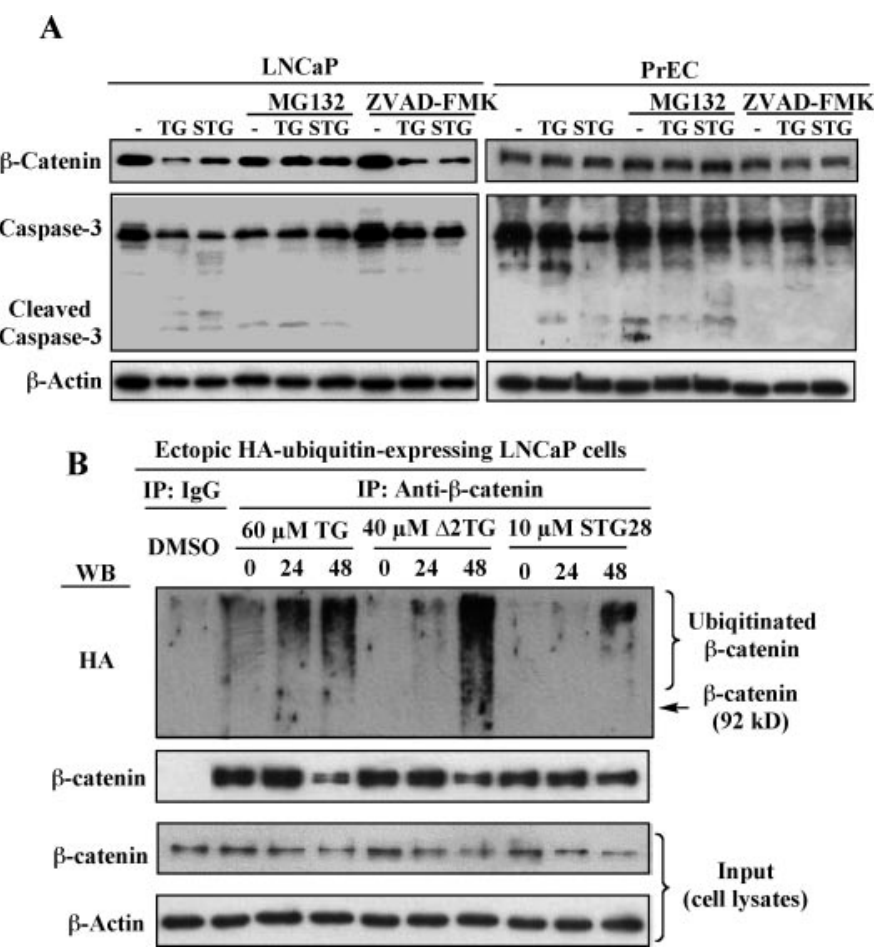

Fig. 3. Evidence that the effect of troglitazone and derivatives on $\beta$-catenin repression is mediated through proteasomal degradation in $\mathrm{LNCaP}$ cells. A, effects of the proteasome inhibitor MG132 and the caspase inhibitor ZVAD-fmk on rescuing the drug-induced $\beta$-catenin repression. Cells were exposed to $60 \mu \mathrm{M}$ TG or $10 \mu \mathrm{M}$ STG28 in 10\% FBS-supplemented medium for $48 \mathrm{~h}$ in the presence of $10 \mu \mathrm{M}$ MG132 or $100 \mu \mathrm{M}$ ZVAD-fmk for $48 \mathrm{~h}$. B, time-dependent effects troglitazone $(60 \mu \mathrm{M}), \Delta 2 \mathrm{TG}$ $(40 \mu \mathrm{M})$, and STG28 (10 $\mu \mathrm{M})$ on increased $\beta$-catenin ubiquitination. Cells were electroporated with $5 \mu \mathrm{g}$ of HA-ubiquitin plasmids and incubated in $10 \%$ FBS-containing medium for $24 \mathrm{~h}$ followed by treatment with individual agents for 24 or $48 \mathrm{~h}$. Equal amounts of cell lysates were immunoblotted with anti- $\beta$-catenin antibodies (input, bottom) or immunoprecipitated with anti- $\beta$-catenin antibodies followed by Western blot analysis with anti-HA and anti- $\beta$-catenin antibodies. vidual agents led to reduced $\beta$-catenin levels (input) accompanied by increased $\beta$-catenin ubiquitination as indicated by a complex ladder of ubiquinated $\beta$-catenin bands.

Troglitazone and Derivatives Suppress $\beta$-Catenin Expression via a GSK3 $\beta$-Dependent Mechanism. It is well-documented that intracellular $\beta$-catenin is tightly controlled by two ubiquitination-dependent proteasomal degradation pathways: adenomatous polyposis coli (APC)-axin/ GSK3 $\beta / \beta$-TrCP (Hart et al., 1999; Liu et al., 2002), and APC/Siah-1 (Liu et al., 2001; Matsuzawa and Reed, 2001). To discern the role of these two pathways, we assessed the effect of troglitazone, $\Delta 2 \mathrm{TG}$, and STG28 on GSK3 $\beta$ phosphorylation and the effect of two GSK3 $\beta$ kinase inhibitors, $\mathrm{LiCl}$ and SB216763, on rescuing STG28-mediated $\beta$-catenin degradation in LNCaP cells. Our data indicate that exposure of LNCaP cells to troglitazone, $\Delta 2 \mathrm{TG}$, and STG28 caused a dose-dependent increase in GSK3 $\beta^{\text {Ser9 }}$ phosphorylation (Fig. $4 \mathrm{~A})$. However, inhibition of GSK3 $\beta$ by $\mathrm{LiCl}$ or SB216763 could protect against STG28-facilitated $\beta$-catenin repression in a dose-dependent manner (Fig. 4B), suggesting that GSK3 $\beta$ played a key role in the drug-induced $\beta$-catenin degradation despite its phosphorylating deactivation. In addition, we examined the effect of this combination treatment on the expression level of $\beta$-TrCP, a putative F-box protein for catenin recognition (see Troglitazone and Derivatives Exhibit Dichotomous Effects on Modulating the Expression of Different SCF F-Box Proteins). Although LiCl or SB216763 by itself could slightly decrease $\beta$-TrCP expression, the GSK3 $\beta$ inhibitor exhibited no appreciable effect on suppressing the ability of STG28 to up-regulate $\beta$-TrCP expression.

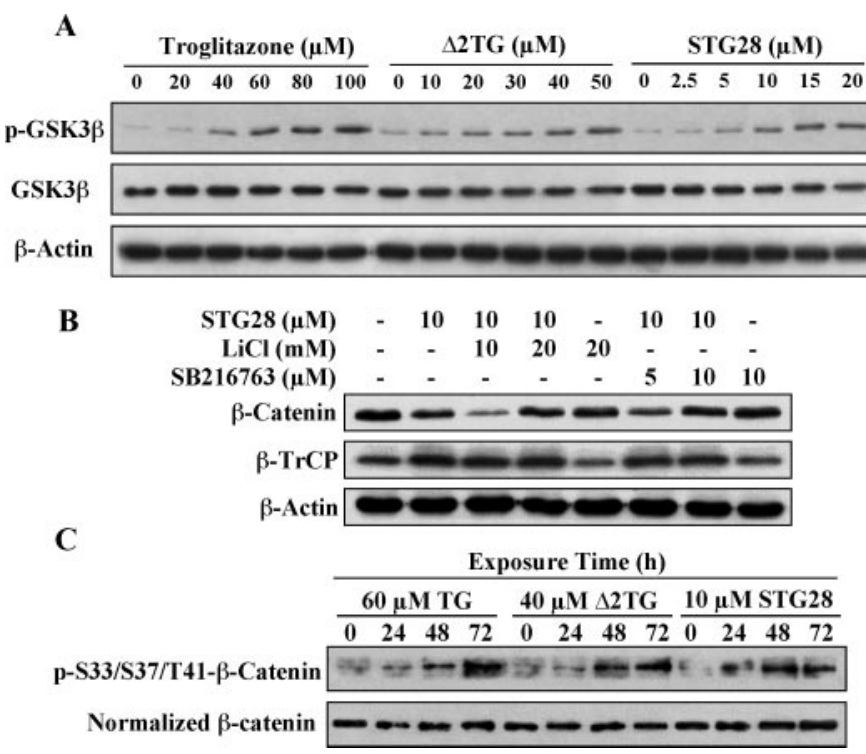

Fig. 4. GSK3 $\beta$ plays a key role in troglitazone-, $\Delta 2$ TG-, and STG28mediated $\beta$-catenin repression despite phosphorylating deactivation. A, LNCaP cells were exposed to different doses of TG, $\Delta 2 \mathrm{TG}$, or STG28 in $10 \%$ FBS-supplemented medium for $72 \mathrm{~h}$, and the phosphorylation status of Ser9-GSK3 $\beta$ was detected by Western blot analysis. B, dose-dependent effects of the GSK3 $\beta$ inhibitors $\mathrm{LiCl}$ and SB216763 on the expression levels of $\beta$-catenin and $\beta$-TrCP in STG28-treated cells. Cells were treated with $10 \mu \mathrm{M}$ STG28 alone or in combination with different doses of $\mathrm{LiCl}$ or SB216763 in 10\% FBS-supplemented medium for $72 \mathrm{~h}$ followed by Western blot analysis. C, time-dependent effect of troglitazone, $\Delta 2 \mathrm{TG}$, and STG28 on $\beta$-catenin phosphorylation at Ser33/Ser37/Thr41, known phosphorylation sites for GSK3 $\beta$. LNCaP cells were treated with individual agents at the indicated concentration for different time intervals, and cell lysates were immunoblotted with anti-p-S33/S37/T41- $\beta$-catenin antibodies after $\beta$-catenin was normalized. 
The premise regarding the central role of GSK3 $\beta$ was corroborated by the correlation between the time-dependent suppression of $\beta$-catenin expression by troglitazone, $\Delta 2 \mathrm{TG}$, and STG28 (Fig. 2A) and the increased phosphorylation of $\beta$-catenin at Ser33/Ser37/Thr41 (Fig. 4C), a known GSK3 $\beta$ phosphorylation site recognized by $\beta$-TrCP (Orford et al., 1997; Sadot et al., 2002). The level of p- $\beta$-catenin was hardly detectable in the absence of drug treatment but increased in a time-dependent manner parallel to that of a decrease in $\beta$-catenin expression when cells were exposed to individual agents.

Together, these findings are in contrast to a previous report that troglitazone mediated $\beta$-catenin degradation via a GSK3 $\beta$-independent pathway in hepatocytes (Sharma et al., 2004). However, this discrepancy might be attributable to differences in the regulation of $\beta$-catenin degradation between LNCaP cells and hepatocytes.

Troglitazone and Derivatives Exhibit Dichotomous Effects on Modulating the Expression of Different SCF F-Box Proteins. Pursuant to the above findings, we examined the effect of these small-molecule agents on the expression levels of three SCF F-box proteins: $\beta$-TrCP, Skp2, and Fbw7 (Fig. 5A). Our data indicate that troglitazone, $\Delta 2 \mathrm{TG}$, and STG28 increased the expression level of $\beta$-TrCP in a dose-dependent manner parallel to that of $\beta$-catenin repression, providing a mechanistic link between these two pharmacological responses. It is noteworthy that STG28-mediated increase in $\beta$-TrCP expression was accompanied by decreased expression of Fbw7 and, to a greater extent, Skp2. This dichotomous effect led to divergent changes in the expression levels of $\beta$-TrCP-targeted versus Fbw7/Skp2-targeted proteins. For example, a series of known $\beta$-TrCP substrates, including Wee1, I $\kappa \mathrm{B} \alpha, \mathrm{Cdc} 25 \mathrm{~A}$, and $\mathrm{NF} \kappa \mathrm{B} / \mathrm{p} 105$, showed dose-dependent decreases in their expression levels as a result of $\beta$-TrCP up-regulation. In contrast, the druginduced down-regulation of Skp2 and Fbw7 led to the accumulation of their substrates p27 and cyclin E.

Reverse transcription-PCR analysis indicates that exposure of LNCaP cells to different doses of STG28 did not affect the mRNA level of $\beta$-TrCP despite a robust increase in its protein level. This finding suggests that the up-regulation of $\beta$-TrCP by STG28 was mediated by prolonging its protein stability. To test this premise, we assessed the effect of STG28 on the half-life of $\beta$-TrCP in LNCaP cells treated with the protein synthesis inhibitor cycloheximide (Fig. 5C). Cells were exposed to DMSO or $10 \mu \mathrm{M}$ STG28 for $12 \mathrm{~h}$ followed by the treatment of $100 \mu \mathrm{g} / \mathrm{ml}$ cycloheximide for different time intervals. In vehicle-pretreated cells, $\beta$-TrCP had a half-life of approximately $6 \mathrm{~h}$ and was almost completely eliminated at $24 \mathrm{~h}$ (left). In contrast, in STG28-pretreated cells, the protein level of $\beta$-TrCP remained unaltered throughout the course of cycloheximide treatment. Based on this finding, we rationalized that STG28 treatment suppressed the turnover of $\beta$-TrCP, resulting in its accumulation in LNCaP cells. Relative to LNCaP cells, PrECs were resistant to STG28mediated $\beta$-TrCP up-regulation (Fig. 5D), which reflected the differential effect of STG28 on suppressing $\beta$-catenin expression and cell viability between malignant and nonmalignant cells.

Evidence that $\beta$-TrCP Is Involved in STG28-Mediated $\boldsymbol{\beta}$-Catenin Proteolysis. Three lines of evidence were obtained to substantiate the involvement of $\beta$-TrCP in
STG28-mediated $\beta$-catenin degradation. First, we used an in vitro pull-down assay to assess the binding of bacterially expressed recombinant GST- $\beta$ - $\mathrm{TrCP}$ with endogenous $\beta$-catenin in the lysates of STG28-treated LNCaP cells (Fig. 6A). LNCaP cells were treated with DMSO or STG28 $(10 \mu \mathrm{M})$ with or without epoxomicin $(10 \mu \mathrm{M})$ for $24 \mathrm{~h}$, and the cell lysates were immunoblotted with $\beta$-catenin antibodies (input) or treated with agarose beads coated with GST- $\beta$-TrCP or GST. Equivalent amounts of the affinity precipitates were subject to Western blotting with antibodies against $\beta$-catenin, $\beta$-TrCP, or GST antibodies. As shown, cotreatment of cells with STG28 and epoxomicin significantly increased the amount of $\beta$-catenin associated with the pull-down.

Second, LNCaP cells were transfected with scrambled siRNA or increasing doses of siRNA against $\beta$-TrCP, and the effect $\beta$-TrCP knockdown on STG28-induced $\beta$-catenin repression was examined (Fig. $6 \mathrm{~B}$ ). As shown, reduced $\beta$-TrCP expression was accompanied by a complete protection against STG28-facilitated $\beta$-catenin ablation. Third, LNCaP cells were nucleofected with $\beta$-TrCP-Myc plasmids and exposed to different doses of STG28. Figure 6C indicates that

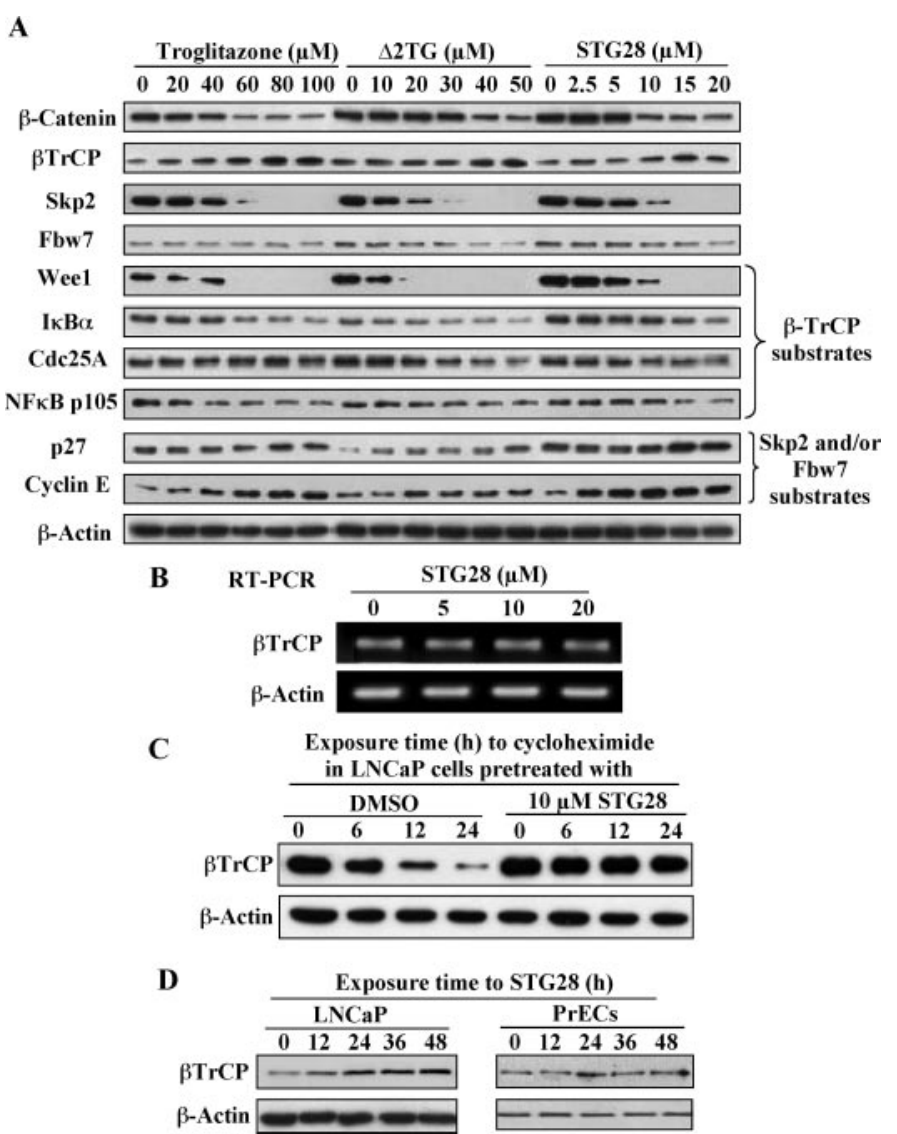

Fig. 5. A mechanistic link between thiazolidinedione-facilitated $\beta$-catenin repression and $\beta$-TrCP up-regulation in LNCaP cells. A, dose-dependent effects of troglitazone, $\Delta 2 \mathrm{TG}$, and STG28 on modulating the expression of the F-box proteins $\beta$-TrCP, Skp2, and Fbw7 and their respective substrates, including Wee1, I $\kappa \beta \alpha, \mathrm{Cdc} 25 \mathrm{~A}, \mathrm{NF} \kappa \mathrm{B} / \mathrm{p} 105$, p27, and cyclin $\mathrm{E}$. Cells were exposed to different doses of individual agents in $10 \%$ FBSsupplemented medium for $72 \mathrm{~h}$. B, STG28 has no effect on $\beta$-TrCP mRNA levels. C, STG28 prolongs $\beta$-TrCP protein half-life. Cells were pretreated with either DMSO or $10 \mu \mathrm{M}$ STG28 in 10\% FBS-supplemented medium for $12 \mathrm{~h}$, and $\beta \operatorname{TrCP}$ protein half-life was examined by exposing to 100 $\mu \mathrm{g} / \mathrm{ml}$ cycloheximide for different time intervals, followed by Western blot analysis. D, differential effects of STG28 $(10 \mu \mathrm{M})$ on the up-regulation of $\beta$-TrCP expression between LNCaP cells and PrECs. 
ectopic $\beta$-TrCP expression enhanced the ability of STG28 to facilitate the proteasomal degradation of $\beta$-catenin.

Pleiotropic Effects of Troglitazone and Derivatives on the Repression of Multiple $\beta$-Catenin Signaling Components. Evidence indicates that $\beta$-catenin exerts the dual function in adhesion and transcription by forming complexes with various components of the E-cadherin and Wnt signaling pathways, respectively (Bienz, 2005; Harris and Peifer, 2005; Brembeck et al., 2006). To assess the specificity of this drug-mediated proteolysis in the context of the these two signaling networks, we examined the effect of troglitazone, $\Delta 2 \mathrm{TG}$, and STG28 on the expression of several of

\section{A In vitro $\beta$ TrCP- $\beta$-catenin interactions}
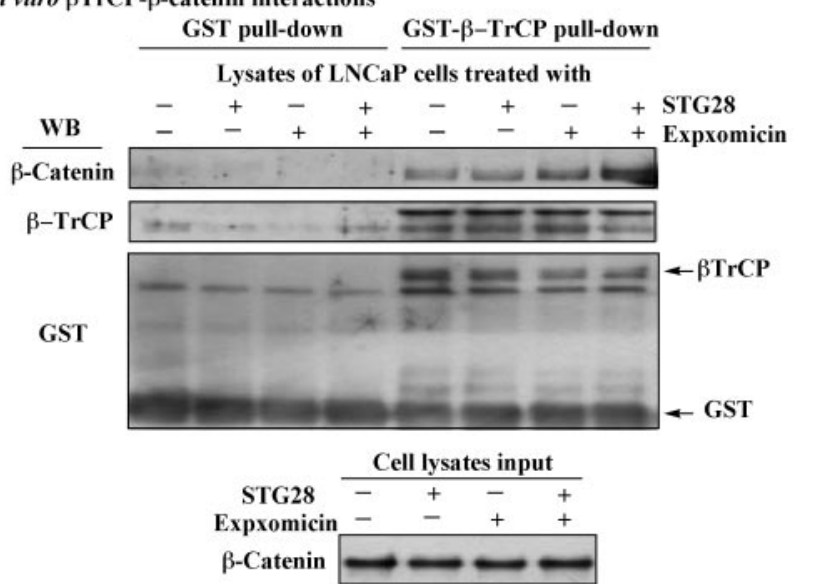

B $\beta$-TrCP knockdown protects against STG28-mediated $\beta$-catenin repression

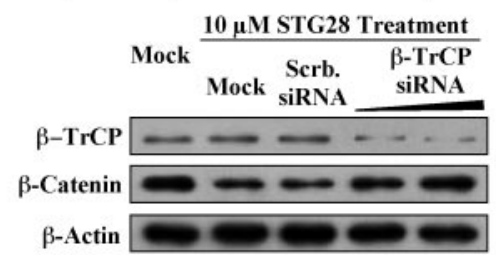

C $\beta$-TrCP overexpression facilitates STG28-mediated $\beta$-catenin repression

\begin{tabular}{|c|c|c|c|c|c|c|c|c|}
\hline \multirow[b]{3}{*}{ STG28 $(\mu \mathrm{M})$} & \multicolumn{8}{|c|}{ LNCaP cells transfected with } \\
\hline & \multicolumn{4}{|c|}{ pCMV } & \multicolumn{4}{|c|}{ p- $\beta$-TrCP-Myc } \\
\hline & 0 & 5 & 10 & 20 & 0 & 5 & 10 & $\overline{20}$ \\
\hline$\beta$-Catenin & - & 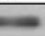 & 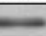 & + & - & 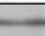 & 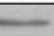 & + \\
\hline$\%$ & 100 & 87 & 67 & 34 & 100 & 63 & 44 & 20 \\
\hline Myc & + & & & & & & & \\
\hline
\end{tabular}

Fig. 6. Evidence that $\beta$-TrCP is involved in STG28-mediated $\beta$-catenin proteolysis in LNCaP cells. A, in vitro pull-down of $\beta$-catenin by bacterially expressed GST- $\beta$-TrCP from lysates of drug-treated versus vehicletreated LNCaP cells. Cells were exposed to DMSO or $10 \mu \mathrm{M}$ STG28, alone or in the presence of epoxomicin, in 10\% FBS-supplemented medium for $24 \mathrm{~h}$, and equal amounts of cell lysates were incubated with recombinant GST- $\beta$-TrCP or GST immobilized onto glutathione beads. The resulting complexes were washed, centrifuged, and subject to Western blot analysis with anti- $\beta$-catenin, $\beta$ TrCP, or GST antibodies (top). One tenth of cell lysates were collected as Input (bottom), and $\beta$-catenin expression was detected. B, siRNA-mediated knockdown of $\beta$ TrCP rescues STG28-induced $\beta$-catenin repression. LNCaP cells were nucleofected with scramble or increasing doses of $\beta \mathrm{TrCP}$ siRNA followed by treatments with DMSO or $10 \mu \mathrm{M}$ STG28 for additional $72 \mathrm{~h}$. Western blot was performed to detect expressions of $\beta$-catenin and $\beta \operatorname{TrCP} . \mathrm{C}$, ectopic expression of $\beta$-TrCP enhances STG28-mediated degradation of $\beta$-catenin. Cells were nucleofected with $5 \mu \mathrm{g}$ of $\mathrm{pCMV}$ or $\beta$-TrCP-Myc plasmids followed by exposure to different doses of STG28 for $72 \mathrm{~h}$. The values shown in percentages denote the relative intensity of protein bands of drug-treated samples compared with that of the respective DMSO vehicle-treated control after being normalized to the respective internal reference $\beta$-actin. $\beta$-catenin's binding partners, including $\alpha$-catenin, plakoglobin (a.k.a., $\gamma$-catenin), E-cadherin, and axin (Fig. 7). As shown, these small-molecule agents caused differential repression of these proteins in the order of plakoglobin $>$ $\alpha$-catenin, E-cadherin $>$ axin. Especially noteworthy is the drug-induced down-regulation of plakoglobin expression, which has been reported to be resistant to APC/axin-dependent proteolytic degradation (Williams et al., 2000).

\section{Discussion}

In light of the pivotal role of aberrant $\beta$-catenin signaling in tumorigenesis (Morin et al., 1997; Wong and Pignatelli, 2002; Verras and Sun, 2006), it has been proposed that the ability of troglitazone to suppress $\beta$-catenin expression could be pharmacologically exploited in cancer prevention (Girnun et al., 2002; Girnun and Spiegelman, 2003). Thus, this study was aimed at elucidating the mechanism by which troglitazone suppresses $\beta$-catenin signaling in cancer cells.

A crucial issue pertinent to troglitazone-mediated $\beta$-catenin degradation was the dependence of this pathway on PPAR $\gamma$ activation. Previous studies in preadipocytes and hepatocytes suggested that the pharmacological action of troglitazone involved a PPAR $\gamma$-dependent targeting of $\beta$-catenin to proteasomal degradation (Moldes et al., 2003; Liu and Farmer, 2004; Sharma et al., 2004). Therefore, it was proposed that the cross-talk between PPAR $\gamma$ and $\beta$-catenin signaling underlay the effect of troglitazone and other PPAR $\gamma$ agonists on cell differentiation and growth inhibition during adipogenesis. In this study, several lines of evidence refuted the involvement of PPAR $\gamma$ in troglitazone-facilitated $\beta$-catenin degradation in prostate cancer cells. First, the ablation of $\beta$-catenin was only observed at suprapharmacological doses of troglitazone $(\geq 40 \mu \mathrm{M})$, which were several orders of magnitude higher than that required for PPAR $\gamma$ activation. In addition, this ablation was not affected by the PPAR $\gamma$ antagonist GW9662. Second, different prostate cancer cell lines were equally susceptible to troglitazone-mediated repression of $\beta$-catenin irrespective of their PPAR $\gamma$ expression levels. Third, $\Delta 2 \mathrm{TG}$ and STG28, although lacking $\operatorname{PPAR} \gamma$ activity, were able to mediate $\beta$-catenin repression with higher potency than troglitazone.

In addition to PPAR $\gamma$, the role of GSK3 $\beta$ in troglitazonemediated $\beta$-catenin degradation warranted investigation in light of contradictory data in the literature (Liu and Farmer, 2004; Sharma et al., 2004). This study indicates that although GSK3 $\beta$ was subject to phosphorylating deactivation

\begin{tabular}{|c|c|c|}
\hline & Troglitazone $(\mu \mathrm{M})$ & STG28 $(\mu \mathrm{M})$ \\
\hline & $\begin{array}{llllllllllll}0 & 20 & 40 & 60 & 80 & 100 & 0 & 10 & 20 & 30 & 40 & 50\end{array}$ & $\begin{array}{llllll}0 & 2.5 & 5 & 10 & 15 & 20\end{array}$ \\
\hline$x$-Catenin & $-\rightarrow-\cdots$ & $---\cdots$ \\
\hline Plakoglobin & $-\ldots \ldots-\cdots \cdots$ & $-\infty-\cdots$ \\
\hline Cadherin & $-\infty-\infty---\cdots$ & $\cdots \cdots \cdots$ \\
\hline Axin & $-----\infty-\infty$ & $-1--$ \\
\hline 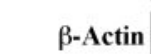 & & \\
\hline
\end{tabular}

Fig. 7. Effects pf troglitazone, $\Delta 2 \mathrm{TG}$, and STG28 on down-regulating multiple components of $\beta$-catenin signaling pathways. LNCaP cells were exposed to different doses of individual agents in 10\% FBS-supplemented medium for $72 \mathrm{~h}$, and equal amounts of cell lysates were subject to Western blot analysis with antibodies against $\alpha$-catenin, plakoglobin ( $\gamma$-catenin), E-cadherin, and axin. 
in response to STG28, it represented a key regulator in the pharmacological effect of STG28 on $\beta$-catenin degradation in prostate cancer cells. Our data suggest that GSK3 $\beta$, albeit with diminished activity, is involved in $\beta$-catenin phosphorylation, which is required for recognition by $\beta$ - TrCP to facilitate subsequent ubiquitination-dependent proteasomal degradation (Liu et al., 1999). This mechanistic link is demonstrated by the findings that pharmacological inhibition of GSK3 $\beta$ or siRNA-mediated knockdown of $\beta$-TrCP could protect against STG28-mediated $\beta$-catenin repression.

Overall, the discrepancy regarding the involvement of PPAR $\gamma$ and GSK3 $\beta$ between this and other studies might be attributed to differences in signaling pathways regulating the turnover of $\beta$-catenin between prostate cancer cells versus adipocytes and hepatocytes. This premise was corroborated by the resistance of normal prostate cancer cells to STG28-mediated repression of $\beta$-catenin and the consequent effect on cell viability.

This study demonstrates that troglitazone and its PPAR $\gamma$ inactive derivatives facilitated ubiquitin-dependent proteasomal degradation of $\beta$-catenin by increasing $\beta$-TrCP expression levels through protein stabilization. As a consequence, many known $\beta$-TrCP substrates, including Wee1, I $\kappa \mathrm{B} \alpha$, Cdc25A, and $\mathrm{NF}_{\kappa} \mathrm{B}$ p105 (Nakayama and Nakayama, 2005, 2006), were also susceptible to the pharmacological effect of these agents.

It is also noteworthy that the drug-induced $\beta$-TrCP upregulation was accompanied by the down-regulation of Skp2 and Fbw7, thereby affecting many of the target proteins of these two F-box proteins such as p27 and cyclin E. As a result, the ability of troglitazone to repress Skp2 and Fbw7 provides a molecular basis to account for its reported effect on up-regulating p27 expression in cancer cells (Koga et al., 2003). Further analysis of protein expression in these drugtreated LNCaP cells showed a dose-dependent reduction in the expression levels of many proteins involved in the $\beta$-catenin signaling network, including $\alpha$-catenin, plakoglobin, Ecadherin, and, to a lesser extent, axin. Although the mechanism underlying the down-regulation of these proteins remains to be elucidated, the pleiotropic effect of troglitazone and its derivatives on suppressing the expression of multiple effector proteins ensured the complete blockade of $\beta$-catenin signaling mechanisms.

Moreover, the modulation of the expression of SCF F-box proteins might also underlies the ability of troglitazone, $\Delta 2 \mathrm{TG}$, and STG28 to repress a series of proteins, including cyclin D1 (Huang et al., 2005), prostate-specific antigen (Yang et al., 2006), and androgen receptor (Yang et al., 2007). For instance, we recently reported that these thiazolidinedione derivatives mediated the repression of androgen receptor and its downstream target prostate-specific antigen by facilitating the proteasomal degradation of the transcription factor Sp1 (Yang et al., 2007). We hypothesize that cyclin D1 and Sp1 are targeted by SCF E3 ligase-facilitated proteasomal degradation, which is currently under investigation.

In summary, this study provides evidence that troglitazone and its PPAR $\gamma$-inactive derivatives modulated the expression of $\beta$-catenin and many cell-cycle regulatory proteins by targeting the F-box proteins of SCF E3 ligase. These smallmolecule agents increased the expression of $\beta$-TrCP while reducing the expression of Skp2 and Fbw7, resulting in changes in the expression profiles of a multitude of proteins involved in the regulation of cell-cycle progression and apoptosis. From a mechanistic perspective, how these smallmolecule agents simultaneously modulate the expression of $\beta-\operatorname{TrCP}$, Skp2, and Fbw7 warrants investigation in light of the importance of the SCF ubiquitin-proteasome system in the regulation of cell-cycle progression and apoptosis.

However, despite this complicated mode of pharmacological mechanism, normal prostate epithelial cells were resistant to the effect of STG28 on proteasomal degradation and reducing cell viability. This discriminative effect between normal versus malignant cells underlies the impetus of using STG28 as a scaffold to develop a novel class of antitumor agents targeting the ubiquitin-proteasome system. This drug discovery effort is currently underway in this laboratory.

\section{References}

Bae MA and Song BJ (2003) Critical role of c-Jun N-terminal protein kinase activation in troglitazone-induced apoptosis of human HepG2 hepatoma cells. Mol Pharmacol 63:401-408.

Baek SJ, Wilson LC, Hsi LC, and Eling TE (2003) Troglitazone, a peroxisome proliferator-activated receptor gamma (PPAR $\gamma$ ) ligand, selectively induces the early growth response-1 gene independently of PPAR $\gamma$. A novel mechanism for its anti-tumorigenic activity. $J$ Biol Chem 278:5845-5853.

Bienz M (2005) beta-Catenin: a pivot between cell adhesion and Wnt signalling. Curr Biol 15:R64-R67.

Brembeck FH, Rosario M, and Birchmeier W (2006) Balancing cell adhesion and Wnt signaling, the key role of beta-catenin. Curr Opin Genet Dev 16:51-59.

Day C (1999) Thiazolidinediones: a new class of antidiabetic drugs. Diabet Med 16:179-192.

Girnun GD, Smith WM, Drori S, Sarraf P, Mueller E, Eng C, Nambiar P, Rosenberg DW, Bronson RT, Edelmann W, et al. (2002) APC-dependent suppression of colon carcinogenesis by PPAR $\gamma$. Proc Natl Acad Sci U S A 99:13771-13776.

Girnun GD and Spiegelman BM (2003) PPARgamma ligands: taking Ppart in chemoprevention. Gastroenterology 124:564-567.

Gouni-Berthold I, Berthold HK, Weber AA, Ko Y, Seul C, Vetter H, and Sachinidis A (2001) Troglitazone and rosiglitazone induce apoptosis of vascular smooth muscle cells through an extracellular signal-regulated kinase-independent pathway. Naunyn Schmiedebergs Arch Pharmacol 363:215-221.

Harris TJ and Peifer M (2005) Decisions, decisions: beta-catenin chooses between adhesion and transcription. Trends Cell Biol 15:234-237.

Hart M, Concordet JP, Lassot I, Albert I, del los Santos R, Durand H, Perret C Rubinfeld B, Margottin F, Benarous R, et al. (1999) The F-box protein beta-TrCP associates with phosphorylated beta-catenin and regulates its activity in the cell. Curr Biol 9:207-210.

Huang JW, Shiau CW, Yang J, Wang DS, Chiu HC, Chen CY, and Chen CS (2006 Development of small-molecule cyclin D1-ablative agents. J Med Chem 49:46844689.

Huang JW, Shiau CW, Yang YT, Kulp SK, Chen KF, Brueggemeier RW, Shapiro CL, and Chen CS (2005) Peroxisome proliferator-activated receptor $\gamma$-independent ablation of cyclin D1 by thiazolidinediones and their derivatives in breast cancer cells. Mol Pharmacol 67:1342-1348.

Kitagawa M, Hatakeyama S, Shirane M, Matsumoto M, Ishida N, Hattori K, Nakamichi I, Kikuchi A, Nakayama K, and Nakayama K (1999) An F-box protein, FWD1, mediates ubiquitin-dependent proteolysis of beta-catenin. EMBO J 18: 2401-2410.

Koeffler HP (2003) Peroxisome proliferator-activated receptor gamma and cancers. Clin Cancer Res 9:1-9.

Koga H, Harada M, Ohtsubo M, Shishido S, Kumemura H, Hanada S, Taniguchi E, Yamashita K, Kumashiro R, Ueno T, et al. (2003) Troglitazone induces p27Kip1associated cell-cycle arrest through down-regulating Skp2 in human hepatoma cells. Hepatology 37:1086-1096.

Latres E, Chiaur DS, and Pagano M (1999) The human F box protein beta-Trcp associates with the Cul1/Skp1 complex and regulates the stability of beta-catenin. Oncogene 18:849-854.

Leesnitzer LM, Parks DJ, Bledsoe RK, Cobb JE, Collins JL, Consler TG, Davis RG, Hull-Ryde EA, Lenhard JM, Patel L, et al. (2002) Functional consequences of cysteine modification in the ligand binding sites of peroxisome proliferator activated receptors by GW9662. Biochemistry 41:6640-6650.

Liu C, Kato Y, Zhang Z, Do VM, Yankner BA, and He X (1999) $\beta$-Trcp couples beta-catenin phosphorylation-degradation and regulates Xenopus axis formation. Proc Natl Acad Sci U S A 96:6273-6278.

Liu C, Li Y, Semenov M, Han C, Baeg GH, Tan Y, Zhang Z, Lin X, and He X (2002) Control of beta-catenin phosphorylation/degradation by a dual-kinase mechanism. Cell 108:837-847.

Liu J and Farmer SR (2004) Regulating the balance between peroxisome proliferator-activated receptor $\gamma$ and $\beta$-catenin signaling during adipogenesis. A glycogen synthase kinase $3 \beta$ phosphorylation-defective mutant of $\beta$-catenin inhibits expression of a subset of adipogenic genes. J Biol Chem 279:45020-45027.

Liu J, Stevens J, Rote CA, Yost HJ, Hu Y, Neufeld KL, White RL, and Matsunami N (2001) Siah-1 mediates a novel beta-catenin degradation pathway linking p53 to the adenomatous polyposis coli protein. Mol Cell 7:927-936.

Matsuzawa SI and Reed JC (2001) Siah-1, SIP, and Ebi collaborate in a novel pathway for beta-catenin degradation linked to p53 responses. Mol Cell 7:915-926. 
Moldes M, Zuo Y, Morrison RF, Silva D, Park BH, Liu J, and Farmer SR (2003) Peroxisome-proliferator-activated receptor gamma suppresses Wnt/beta-catenin signalling during adipogenesis. Biochem $J$ 376:607-613.

Morin PJ, Sparks AB, Korinek V, Barker N, Clevers H, Vogelstein B, and Kinzler KW (1997) Activation of beta-catenin-Tcf signaling in colon cancer by mutations in beta-catenin or APC. Science 275:1787-1790.

Motomura W, Okumura T, Takahashi N, Obara T, and Kohgo Y (2000) Activation of peroxisome proliferator-activated receptor gamma by troglitazone inhibits cell growth through the increase of $\mathrm{p} 27 \mathrm{KiP} 1$ in human. Pancreatic carcinoma cells Cancer Res 60:5558-5564.

Nakayama KI and Nakayama K (2005) Regulation of the cell cycle by SCF-type ubiquitin ligases. Semin Cell Dev Biol 16:323-333.

Nakayama KI and Nakayama K (2006) Ubiquitin ligases: cell-cycle control and cancer. Nat Rev Cancer 6:369-381.

Okura T, Nakamura M, Takata Y, Watanabe S, Kitami Y, and Hiwada K (2000 Troglitazone induces apoptosis via the p53 and Gadd45 pathway in vascular smooth muscle cells. Eur J Pharmacol 407:227-235.

Orford K, Crockett C, Jensen JP, Weissman AM, and Byers SW (1997) Serine phosphorylation-regulated ubiquitination and degradation of beta-catenin. J Biol Chem 272:24735-24738.

Qin C, Burghardt R, Smith R, Wormke M, Stewart J, and Safe S (2003) Peroxisome proliferator-activated receptor gamma agonists induce proteasome-dependent degradation of cyclin D1 and estrogen receptor alpha in MCF-7 breast cancer cells Cancer Res 63:958-964.

Sadot E, Conacci-Sorrell M, Zhurinsky J, Shnizer D, Lando Z, Zharhary D, Kam Z, Ben-Ze'ev A, and Geiger B (2002) Regulation of S33/S37 phosphorylated betacatenin in normal and transformed cells. J Cell Sci 115:2771-2780.

Seargent JM, Yates EA, and Gill JH (2004) GW9662, a potent antagonist of PPARgamma, inhibits growth of breast tumour cells and promotes the anticancer effects of the PPARgamma agonist rosiglitazone, independently of PPARgamma activation. Br J Pharmacol 143:933-937.

Sharma C, Pradeep A, Wong L, Rana A, and Rana B (2004) Peroxisome proliferator activated receptor gamma activation can regulate $\beta$-catenin levels via a proteasome-mediated and adenomatous polyposis coli-independent pathway. $J$ Biol Chem 279:35583-35594

Shiau CW, Yang CC, Kulp SK, Chen KF, Chen CS, Huang JW, and Chen CS (2005 Thiazolidenediones mediate apoptosis in prostate cancer cells in part through inhibition of Bcl-xL/Bcl-2 functions independently of PPARgamma. Cancer Res 65:1561-1569.

Steinhusen U, Badock V, Bauer A, Behrens J, Wittman-Liebold B, Dorken B, and Bommert K (2000) Apoptosis-induced cleavage of $\beta$-catenin by caspase- 3 results in proteolytic fragments with reduced transactivation potential. J Biol Chem 275: $16345-16353$.

Sugimura A, Kiriyama Y, Nochi H, Tsuchiya H, Tamoto K, Sakurada Y, Ui M, and Tokumitsu Y (1999) Troglitazone suppresses cell growth of myeloid leukemia cell lines by induction of p21WAF1/CIP1 cyclin-dependent kinase inhibitor. Biochem Biophys Res Commun 261:833-837.

Takeda K, Ichiki T, Tokunou T, Iino N, and Takeshita A (2001) 15-Deoxy- $\Delta$ 12,14 prostaglandin J2 and thiazolidinediones activate the MEK/ERK pathway through phosphatidylinositol 3-kinase in vascular smooth muscle cells. J Biol Chem 276: $48950-48955$

Verras M and Sun Z (2006) Roles and regulation of Wnt signaling and beta-catenin in prostate cancer. Cancer Lett 237:22-32.

Weng JR, Chen CY, Pinzone JJ, Ringel MD, and Chen CS (2006) Beyond peroxisome proliferator-activated receptor gamma signaling: the multi-facets of the antitumor effect of thiazolidinediones. Endocr Relat Cancer 13:401-413.

Williams BO, Barish GD, Klymkowsky MW, and Varmus HE (2000) A comparative evaluation of beta-catenin and plakoglobin signaling activity. Oncogene 19:5720 5728.

Winston JT, Strack P, Beer-Romero P, Chu CY, Elledge SJ, and Harper JW (1999) The SCFbeta-TRCP-ubiquitin ligase complex associates specifically with phosphorylated destruction motifs in IkappaBalpha and beta-catenin and stimulate IkappaBalpha ubiquitination in vitro. Genes Dev 13:270-283.

Wong NA and Pignatelli M (2002) Beta-catenin-a linchpin in colorectal carcinogenesis? Am J Pathol 160:389-401.

Yang CC, Ku CY, Wei S, Shiau CW, Chen CS, Pinzone JJ, Ringel MD, and Chen CS (2006) Peroxisome proliferator-activated receptor $\gamma$-independent repression of prostate-specific antigen expression by thiazolidinediones in prostate cancer cells. Mol Pharmacol 69:1564-1570.

Yang CC, Wang YC, Wei S, Lin LF, Chen CS, Lee CC, Lin CC, and Chen CS (2007) Peroxisome proliferator-activated receptor gamma-independent suppression of androgen receptor expression by troglitazone mechanism and pharmacologic exploitation. Cancer Res 67:3229-3238.

Yang CS, Yu C, Chuang HC, Chang CW, Chang GD, Yao TP, and Chen H (2005 FBW2 targets GCMa to the ubiquitin-proteasome degradation system. $J$ Biol Chem 280:10083-10090.

Address correspondence to: Dr. Ching-Shih Chen, College of Pharmacy, 336 Parks Hall, The Ohio State University, 500 West $12^{\text {th }}$ Avenue, Columbus, OH 43210. E-mail: chen.844@osu.edu 